\title{
Ruptured caesarean scar ectopic pregnancy: a rare case report
}

\author{
Shikha Jain*, Swati Chaudhary, Neha Jain, Rita Ranjan
}

DDU hospital New Delhi, India, 110064

Received: 03 September 2015

Accepted: 30 October 2015

\section{*Correspondence:}

Dr. Shikha Jain,

E-mail: shikhajaingwalior@gmail.com

Copyright: (C) the author(s), publisher and licensee Medip Academy. This is an open-access article distributed under the terms of the Creative Commons Attribution Non-Commercial License, which permits unrestricted non-commercial use, distribution, and reproduction in any medium, provided the original work is properly cited.

\begin{abstract}
Caesarean scar pregnancy is a rare type of ectopic pregnancy. Little is known about its incidence and natural history. With increasing incidence of caesarean section worldwide, more and more cases are diagnosed and reported. We report a case of caesarean scar site ruptured ectopic pregnancy presented to emergency department with hypovolemic shock. Decision for emergency laparotomy was taken on the basis of clinical findings and ultrasonography. Hemoperitoneum of 2 litres with scar site rupture ectopic was seen. Evacuation of products along with repair of uterus in 2 layers with bilateral tubal ligation was done. It is the rarest kind of ectopic pregnancy and may lead to severe life threatening complications such as uterine rupture and severe hemorrhage or may have adverse effect on future fertility.
\end{abstract}

Keywords: Caesarean, Ectopic, Ultrasound

\section{INTRODUCTION}

The first case of a CS ectopic pregnancy was reported in 1978. ${ }^{1}$ Implantation of a pregnancy within a Caesarean fibrous tissue scar is considered to be the rarest form of ectopic pregnancy and a life-threatening condition. This is because of the very high risk for uterine rupture and all the maternal complications related to it. The most probable mechanism that can explain scar implantation is that there is invasion of the myometrium through a microtubular tract between the caesarean section scar and the endometrial canal. Such a tract can also develop from the trauma of other uterine surgery, e.g. curettage, myomectomy, metroplasty, hysteroscopy and even manual removal of placenta.

A recent case series estimates an incidence of 1:2226 of all pregnancies, with a rate of $0.15 \%$ in women with a previous caesarean section and a rate of $6.1 \%$ of all ectopic pregnancies in women who had at least one caesarean delivery. ${ }^{2}$ Although expectant and medical management have been reported, termination of a caesarean scar pregnancy by laparotomy and hysterotomy, with repair of the accompanying uterine scar dehiscence, may be the best treatment option.

\section{CASE REPORT}

A 26 year old female, G4P3L2, with a previous history of two normal deliveries followed by a casearean 1year back but the baby died after some days of birth presented with 12 weeks of gestation in emergency on 8th august 2015 for lower abdominal pain since 1 day, mild vaginal bleeding and vomiting since morning. On examination patient was conscious, oriented and pale. Her pulse rate was $112 / \mathrm{min}$, BP was $90 / 60 \mathrm{~mm} \mathrm{Hg}$, RR was $18 /$ minute. Per abdomen examination revealed distention with guarding and rigidity. Per speculum examination showed pale vaginal mucosa, slight bleeding through os. Uterine size could not be made out on per vaginal examination but both fornices were found to be free and tender .Her urine pregnancy test was positive. Investigations were sent meanwhile the patient was resuscitated with fluids. $\mathrm{Hb}$ reported was $6.5 \%$, rest investigations were normal. 
Trans abdominal ultrasound revealed 9 weeks gestational sac with cardiac activity situated in lower part of uterus near cervix. Free fluid was seen in abdominal cavity and pouch of Douglas. Exploratory laparotomy was done under general anaesthesia. Approximate 2 liters of haemoperitoneum with ruptured uterine scar from right side was found. Amniotic sac with placenta was seen attached at the rupture site. Uterus size was around 8-10 weeks. Sac with placenta was removed out followed by repair of uterus in two layers with bilateral tubal ligation after taking consent. Two units of packed cells were transfused intraoperatively and one unit postoperatively. Her postoperative period was uneventful.

\section{DISCUSSION}

Caesarean scar pregnancy is the rarest kind of ectopic pregnancy, but because of the increasing number of cesarean deliveries its incidence has been rising to be about 1/2000 normal pregnancy. Of all reported pregnancies 1 to $2 \%$ are ectopic, which include the cesarean / hysterotomy scar ectopic pregnancy whose incidence is about $6.1 \%$ of all ectopic pregnancies. Caesarean scar pregnancy may present from as early as 5-6 weeks to as late as 16 weeks. ${ }^{2,3}$ In our case pt. was admitted at 12 weeks. A study done by Ash A et al found the mean gestational age at diagnosis $7.5 \pm 2.5$ weeks and the time interval between the last caesarean section and the caesarean scar pregnancy was 6 months to 12 years. ${ }^{4}$ In our case study the time interval was 12 months. TVS on its own has a diagnostic sensitivity of $86.4 \%(95 \% \mathrm{CI}$ $0.763-0.9050) .{ }^{5}$ Additional diagnostic information can be obtained by colour flow doppler. Several types of conservative treatment have been used such as dilatation and curettage, excision of trophoblastic tissues (laparotomy or laparoscopy), local and/or systemic administration of methotrexate, bilateral hypogastric artery ligation associated with trophoblastic evacuation, and selective uterine artery embolization combined with curettage and/or MTX administration. But many patients finally require surgical treatment as study done by Stevens et al. reported the failed combination of local and systemic methotrexate management finally requiring surgical intervention. ${ }^{6}$ In our case patient presented with hypovolumic shock with rupture ectopic at scar site.We did laparotomy with evacuation of products and repair of uterus in two layers and bilateral tubal ligation. Similar case was reported by Nankali et al and Singh et al and the same treatment approach was adopted. ${ }^{7,8}$

\section{CONCLUSIONS}

Embryo implantation in the region of a previous caesarean section scar is a rare but potentially catastrophic complication of a previous caesarean birth. Hence it is important to have early and accurate diagnosis to avoid complications and preserve fertility.

Funding: No funding sources

Conflict of interest: None declared

Ethical approval: Not Required

\section{REFERENCES}

1. Larsen JV, Solomon MH. Pregnancy in a uterine scar sacculus: an unusual cause of postabortal haemorrhage. S AfrMed J. 1978;53:142-3.

2. Seow K-M, Huang L-W, Lin YH, Yan-Sheng Lin M, Tsai Y-L, Hwang J-L. Caesarean scar pregnancy: issues in management. Ultrasound Obstet Gynecol. 2004;23:247-53.

3. Smith A, Maxwell D, Ash A. Sonographic diagnosis of caesarean scar pregnancy at 16 weeks. J Clin Ultrasound. 2007;35(4):212-5.

4. Ash A, Smith A, Maxwell D. Caesarean scar pregnancy. BJOG 2007;114(3):253-63.

5. Rotas MA, Haberman S, Levgur M. Cesarean scar ectopic pregnancies: etiology, diagnosis and management. Obstet Gynecol 2006;107:1373-7.

6. Stevens EE, Ogburn P. Cesarean scar ectopic pregnancy: a case report of combination local and systemic methotrexate management requiring surgical intervention. J Reprod Med. 2011;56(78):356-8.

7. Nankali A, Ataee M, Shahlazadeh H, Daeich S. Surgical Management of the Cesarean Scar Ectopic Pregnancy: A Case Report Case Reports in Obstetrics and Gynecology. 2013, Article ID 525187, 3 pages. Doi:10.1155/2013/525187.

8. Singh K, Soni A, Rana S. Ruptured Ectopic Pregnancy in Caesarean Section Scar: A Case Report. Case Reports in Obstetrics and Gynecology Volume 2012 (2012), Article ID 106892, 3 pages. doi: $10.1155 / 2012 / 106892$

Cite this article as: Jain S, Chaudhary S, Jain N, Ranjan R. Ruptured caesarean scar ectopic pregnancy: a rare case report. Int J Reprod Contracept Obstet Gynecol 2015;4:2111-2. 